\title{
Analysis of the Determinants of the Technical Efficiency of Horticultural Production in the Face of the Degradation of Water Reservoirs in Urban Centers in Burkina Faso
}

\author{
Olivier COMBELEM* \\ Course instructor, New Dawn University, Burkina Faso \\ Tibi Didier ZOUNGRANA \\ Department of economics, University Ouaga II, Burkina Faso \\ Samuel YONKEU \\ Department of environmental management, New Dawn University, Burkina Faso
}

\begin{abstract}
Horticulture activity represents one of the most important sources of income for the populations living near the water reservoirs in the city of Ouagadougou. However, its production is threatened by the increasingly and pronounced deterioration of reservoirs. In this article, we aim to measure the technical efficiency of horticulturalists in such a context. To achieve this goal, the stochastic production frontier method was carried out on a representative sample of 128 horticultural operators. The outcomes of the research reveal that overall horticulturalists are not technically efficient. In fact, the average level of technical efficiency is 0.68 . The technical inefficiency evaluated to 0.32 is mainly due to the social status of the operator, the location of the plot with respect to the flow of water, and the poor state of water and soil.
\end{abstract}

Keywords: Horticulture, Coelli and Battesse model, Technical efficiency, Water reservoirs

DOI: $10.7176 / \mathrm{JESD} / 11-12-13$

Publication date:June 30th 2020

\section{Problem statement}

Burkina Faso is a Sahelian country which economy mainly relies on agriculture and livestock (MINEFID, 2016). The rural sector that count for more than $80 \%$ of the active population (Zoungrana, 2017) constitutes the economic lung of the country with a contribution of $40 \%$ to the GDP of which $30.7 \%$ is dependent on the agricultural sector. However, rainfall fluctuations, characterized by a significant spatiotemporal variability jeopardize yields (Zongo et al., 2019).

This situation impedes food security objectives and puts the country in a situation of food insecurity. In a context of climate change, partial or total control of the water resource through storage structures and the development of water reservoirs for irrigation purposes remains a solution for achieving the food security objective in Burkina Faso (Bougaire, 2008; Kambou, 2019). These actions led to the adoption of a water resource mobilization's strategy. The water resource mobilization policy in Burkina Faso dates back to the early 1970s. It was dictated on the one hand by the great droughts experienced by the country on the 1970s and on the other hand by the telescoping of three essential needs: an increasing need for drinking water, a non-negligible industrial need and a need for intensification and diversification of agricultural production through the extension and intensification of the practice of irrigated agriculture. The construction of dams has been one of the major elements of development policy in rural and urban areas (FAD, 2002; CECCHI et al., 2009). The potential offered by these water storage structures are significant, because the volumes of water stored, most often intended to meet the needs of humans and animals, also allow the development of irrigated crops, especially rice, market gardening, horticulture and fishing (Yonkeu and Mamane, 2007; Atinkpahoun et al., 2018). This is the case of the water reservoirs in the city of Ouagadougou, which constitute an illustrative example of multiple-use of water in urban area (Boland, 2005; Ouédraogo et al., 2018). Indeed, the construction of water reservoirs in the city of Ouagadougou on one of the tributaries of the Nakambé basin, should allow the city's populations to have a source of drinking water. With a cumulative capacity of 14,960,000 $\mathrm{m} 3$, these reservoirs contributed, with that of Loumbila, to almost $30 \%$ of the supply of drinking water in the city of Ouagadougou (Yaméogo, 2008). In addition to their vocation of supplying drinking water, these hydraulic infrastructures, joined to the Bangr-Weogo forest, constitute the main ecological lungs of the city. They play a role in recharging the water table and serve as buffer zones for preserving inhabitants against flooding and developing tourist assets by facilitating the practice of recreational activities (AEN1, 2015). In addition, water withdrawn from dams is used as one of the essential inputs in most Income-Generating Activities (Atidegla et al., 2017; Tidjani et al., 2018). It is mainly horticultural crop,

\footnotetext{
${ }^{1}$ AEN stands for Nakambé Agency of Water
} 
considered as an income-generating activity for the neighboring populations (Sawadogo, 2008; Conchita et al., 2010; Ouédraogo et al., 2018).

However, these water reservoirs are nowadays affected by a continuous degradation characterized by silting up and pollution. The silting up generally results from the strong presence of solid waste resulting from human activities (Zoungrana and Combelem, 2016). This phenomenon poses a real problem of water availability in reservoirs and will be accentuated if management efforts are not undertaken (Ouédraogo, 2010). As for pollution, it results from certain practices of residents, which are likely to deteriorate the quality of water in reservoirs. Indeed, some families connect their toilets to water reservoirs, thus emitting a foul odor that scares away any "sensible" person (AEN, 2015). In addition, the hyacinth found on the surface of dams' water constitutes a harmful plant to water quality. All these factors are likely to threaten the existence of dams in the long run. Moreover, with the deterioration of the water reservoirs, several economic activities of local residents are threatened. These include fishing, market gardening and horticulture. Among these activities, horticulture or the cultivation of ornamental plants is the most dominant and practiced by the majority of operators (Combelem, 2019). This worrying situation therefore deserves consideration of the impact of the current state of these reservoirs on the technical efficiency of horticulturalists in the logic where the quality and quantity of the resources mobilized for production (land, water, inputs, labor, capital) would be determining factors in agricultural production in general (Fuglie and Rada, 2013; Douillet and Girard, 2013) and in horticultural production in particular (Ouédraogo et al., 2018). Thus, in view of the continuous deterioration of the reservoirs, the evaluation of the technical efficiency of horticulturalists is necessary to conclude on the real impact of the economic activities carried out.

The objective of this article is to estimate on the one hand the level of technical efficiency of horticulturalists around the water reservoirs of the city of Ouagadougou and, on the other hand, to analyze the factors explaining the technical inefficiency of these operators. This article begins with a review of the literature, which exposes the theoretical debate on measuring efficiency before briefly presenting the methodological approach used for data collection and the analysis model. Subsequently, the econometric results are presented and analyzed.

\section{Analytical framework: A measurement of technical efficiency by the stochastic frontier production approach.}

The neoclassical theory based on pure and perfect competition has dealt with problems of efficiency or performance of production units (Djimasra, 2009). Indeed, it assumes that the production unit operates in a perfectly competitive market and is economically efficient. In addition, neoclassics believe that uncertainty and errors in forecasting can be a source of economic inefficiency, but this inefficiency can only be temporary or accidental (Combary and Sawadogo, 2014). That led to make strong criticisms against this theory.

For Agbodan and Amoussouga (1995), presenting the productive units as evolving in a regime of full competition, meaning pure and perfect, is far from being the reality. In practice, productive units are in imperfect competition, and the risks of permanent inefficiency are not excluded. In fact, according to these authors, no economic regime can guarantee that the productive units will always act in such a way as to behave as efficiently, respecting the behaviors that are expected from them. Leibenstein (1966) developed the concept of inefficiency$\mathrm{X}$ to show essentially that for one reason or another, performance in the productive unit is not as effectively efficient in driving it towards its objective of maximization. According to this author, inefficiency- $\mathrm{X}$ is the type of inefficiency resulting from the misuse of resources within productive units.

Later, the new neoclassical microeconomics succeeded in making the neoclassical producer theory compatible with the theory of inefficiency-X in the context of imperfect markets. In the presence of transaction costs, information imperfection and strategic behavior, a production unit can be technically inefficient, even if it is intentionally rational (Arrow, 1974; Akerlof, 1970; Stiglitz, 1977; Williamson, 1985).

Empirically, the technical inefficiency of a productive unit can be measured from either the output perspective or the input perspective. The first case involves the estimation of a production border while under the second case, it is done by estimating a border cost. In the output perspective, the production boundary provides each time the maximum output achievable through the use of a vector of available inputs while applying a given production technology. Consequently, the border is a kind of envelope, which often coincides with all the points identified as representative of rational behavior in relation to which the actual performance of each operator can be compared (Ambapour, 2001). The production units located on this border are technically considered to be the most efficient and therefore have a score equal to 1 . In addition, any deviation from this border is equivalent to the level of inefficiency. Theoretically, the efficiency score ranges between 0 and 1 . The most technically efficient unit is the one that produces the same amount of output with the lowest volume of inputs. In this case, the technical efficiency index can be presented as the ratio of the optimal volume of inputs over the volume actually used.

In the literature, two main methods are identified for estimating technical efficiency: the parametric and the non-parametric methods. The choice of estimation method depends on the specification or the functional form of the production frontier. Indeed, the parametric approach is based on a particular specification of the production function, which parameters must be estimated. This is not the case with the non-parametric approach, which is 
characterized by the absence of constraints on the functional form of the production boundaries (Aigner et al., 1977; Charnes, et al., Cooper and Rhodes, 1978). Technical efficiency is measured from the error term of the production function. There are deterministic and stochastic production boundaries at this level. Farell (1957) and Aigner and Chu (1968) pioneered analysis in terms of deterministic parametric production boundaries. However, their approach was questioned because it was too simplistic; any difference between border production and observed production was exclusively attributed to the operator's inefficiency. However, other factors can escape the operator's control while they have a real influence on his performance. This is for example the case of climatic vagaries, the inadequate yield of certain production factors. Considering all of these ineffective factors requires an appropriate specification of the production frontier, which takes into account these parameters of integrating the random effects: this is how the approach of the stochastic frontier was developed. The approach is based on the decomposition of the error term into two components, which captures the operator's inefficiency and that of a random nature combining measurement errors and exogenous shocks (Coelli and Battesse, 1998). It has been judged to be the most suitable for measuring the efficiency of productive units using several inputs to produce several outputs and it is recommended also when the production technique is uncertain or unknown (Gunther and Chauveau, 2002). In this article, the production frontier with incorporated technical inefficiency effects (Battese and Coelli, 1995) can then be written as follows:

$$
\mathrm{Y}_{\mathrm{i}}=\mathrm{f}\left(\mathrm{X}_{\mathrm{i}} ; \beta\right) \mathrm{e}^{\left(\mathrm{V}_{\mathrm{i}}-\mathrm{U}_{\mathrm{i}}\right)} \text { with } \mathrm{U}_{\mathrm{i}}=\mathrm{h}\left(\mathrm{Z}_{\mathrm{i}} ; \alpha\right)
$$

where $\mathrm{Y}$ represents the actual production; $\mathrm{X}$ is a vector of production factors; $\beta$ is the vector of parameters to be estimated; e the exponential function; $\mathrm{V}$ is a random error term which captures stochastic effects that are not under the control of the operator; $U$ represents technical inefficiency, meaning the difference between the potential production and the actual production of the operators; $\mathrm{Z}$ represents the socio-economic characteristics likely to explain the technical inefficiency of the operators; $\alpha$ the vector of unknown parameters to estimate determinants of inefficiency; $\mathrm{f}($.) represents the functional relationship associated with the frontier of production technology and $\mathrm{h}($.$) represents the functional relationship associated with technical inefficiency.$

A production unit is technically efficient if and only if it reaches the maximum output compatible with the available production technology and the vector of inputs. Authors such as Mabe et al., (2018), Abdulai et al., (2018) and Danso-Abbeam, (2015) defined the technical efficiency of an individual farm household as the ratio of observed production to corresponding frontier production conditioned on the level of inputs used by the farm household. They therefore specify the technical efficiency "TE" as follows (Dieng et al., 2019):

$$
\mathrm{TEi}=\frac{\mathrm{Y}_{\mathrm{i}}}{\mathrm{Y}_{\mathrm{i}}^{*}}=\frac{\mathrm{f}\left(\mathrm{X}_{\mathrm{i}}, \beta\right) \cdot \mathrm{e}^{\mathrm{v}_{\mathrm{i}}-\mathrm{U}_{\mathrm{i}}}}{\mathrm{f}\left(\mathrm{X}_{\mathrm{i}}, \beta\right) \cdot \mathrm{e}^{\mathrm{v}_{\mathrm{i}}}}=\mathrm{e}^{(-\mathrm{u})} ; 0 \leq \mathrm{e}^{(-\mathrm{u})} \leq 1
$$

When $\mathrm{e}^{(-\mathrm{u})}=1$, the production unit is technically efficient, meaning that the actual production is equal to the potential production. Otherwise, the production unit is technically inefficient.

\section{Econometric approach}

In the majority of empirical studies, the estimation of technical efficiency was carried out in two stages (Amara and Romain, 2000). In a first step, the technical efficiency scores were estimated; then these scores were estimated on explanatory variables that were likely to affect the performance of production units using a new model based on the ordinary least squares method or a dichotomous model (Tobit, Logit, Probit) to take into account the truncated nature of the efficiency score variable and which takes its values only in the interval $[0,1]$. The advantage of this approach resides in the fact that in the event of a specification error in the second step, the specification bias only affects the estimated coefficients, thus sparing the coefficients of the border. However, this approach has been called into question since, going from the first stage to the second, the traditional hypothesis of independence of errors terms is abandoned (Amara et al., 2000). In response to these criticisms, new approaches have been developed in order to simultaneously estimate the frontier of stochastic production and the impact of the factors explaining the differences in technical efficiency between the productive units. This is why Huang and Liu's (1994) model was developed to take into account the interactions between the variables that characterize inefficiency on the one hand, and the factors of production on the other. Adopting non-neutral stochastic boundary functions, this model considers that the marginal impact of the production factors is a function of the specific characteristics of each producing unit. Subsequently, Battesse and Coelli (1995) developed an improved variant of this model, which today is considered as a reference model allowing the simultaneous estimation of the stochastic production frontier and the effects of variables reflecting the effects of producing unit characteristics on technical inefficiency scores. This model is most suitable for the estimation of the production function and the determinants of technical inefficiency in the context of this article.

In this article, the estimation of the level of technical efficiency of horticulturalists was carried out through a stochastic production frontier function of trans logarithmic type (Christensen, Jorgenson and Lau, 1973; Coulibaly et al., 2017; Diop et Ka, 2020). This function provides greater flexibility in modeling the technology. Indeed, the translog functional form imposes fewer constraints on the production structure, the elasticity levels of substitutions and scale efficiency while allowing econometric analysis. In addition, it makes it possible to take into account the 
interactive effects between the production factors (Liu et al., 2019). Theoretically, it looks like this:

$$
\text { Lny }=\beta_{0}+\sum_{\mathrm{k}=1}^{\mathrm{n}} \beta_{\mathrm{k}} \operatorname{Lnx}_{\mathrm{k}}+\frac{1}{2} \sum_{\mathrm{k}=1}^{\mathrm{n}} \sum_{\mathrm{t}=1}^{\mathrm{n}} \beta_{\mathrm{kl}} \operatorname{Lnx}_{\mathrm{k}} \operatorname{Lnx}_{\mathrm{l}}+\mathrm{V}_{\mathrm{i}}-\mathrm{U}_{\mathrm{i}}
$$

where Ln refers to the natural log; $y$ : total output, $x_{k}$ : production factor $k$, $\left(\beta_{0}, \beta_{k}, \beta_{k l}\right)$ unknown parameters to be estimated and $\mathrm{n}$ the number of production factors. The translog function is reduced to that of Cobb-Douglass when $\beta_{\mathrm{kl}}=0$ (for all $\mathrm{k}$ and $\mathrm{l}$ ).

It is important to note that from a trans log function, the estimated coefficients are not directly interpretable (for example in the case of the Cobb-Douglas function). It is necessary to calculate the elasticities of the production factors considered which are given by the following formula (Ngom et al., 2016):

$$
\mathrm{e}_{\mathrm{k}}^{1}=\frac{\partial \ln \mathrm{y}_{\mathrm{i}}}{\partial \ln \mathrm{x}_{\mathrm{ki}}}
$$

From equation 3 , the empirical model of the trans log production of stochastic border to identify the factors influencing horticultural production levels is specified as follows:

$$
\begin{aligned}
& \operatorname{Lny}_{\mathrm{i}}=\beta_{0}+\beta_{1} \text { LnQwat }_{\mathrm{i}}+\beta_{2} \ln \operatorname{Surf}_{\mathrm{i}}+\beta_{3} \operatorname{LnExp}_{\mathrm{i}}+\beta_{4} \operatorname{Ln}_{\text {Work }_{\mathrm{i}}}+\frac{1}{2} \beta_{11} \text { LnQwat }_{\mathrm{i}}{ }^{2}+\frac{1}{2} \beta_{22} \operatorname{LnSurf}_{\mathrm{i}}{ }^{2}+
\end{aligned}
$$

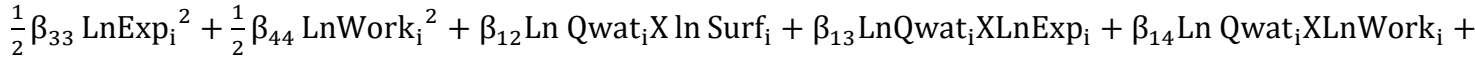

$$
\begin{aligned}
& \beta_{23} \ln \operatorname{Surfy}_{\mathrm{i}} \mathrm{XLnExpy}_{\mathrm{i}}+\beta_{24} \ln \operatorname{Surf}_{\mathrm{i}} \mathrm{X} \operatorname{LnWork}_{\mathrm{i}}+\beta_{34} \operatorname{LnExp}_{\mathrm{i}} \mathrm{XLn} \text { Work }_{\mathrm{i}}+\mathrm{Vi}-\mathrm{Ui}
\end{aligned}
$$

The model estimating the determinants of technical inefficiency is written as follows:

$$
\mathrm{U}_{\mathrm{i}}=\alpha_{0}+\sum_{\mathrm{j}=1}^{\mathrm{k}} \alpha_{\mathrm{ji}} \mathrm{Z}_{\mathrm{ji}}+\varepsilon_{\mathrm{i}}
$$

Where Yi represents the quantity produced by the operator $\mathrm{i}$ in terms of number of plants $(\mathrm{i}=1.2, \ldots, 128)$; Qwat $_{i}$ is the amount of water in liters used by the operator $i$ (Albouchi et al., 2007); Exp $p_{i}$ is the operator's input expenditure and expressed in CFA francs ${ }^{1}$ (Bachewe et al., 2015); Surf $\mathrm{f}_{\mathrm{i}}$ is the area of farm $\mathrm{i}$ in hectares (Chogou et al., 2017); Work $\mathrm{i}_{\mathrm{i}}$ is the amount of work expressed in hours (Ben Nasr et al., 2016); $\mathrm{Z}_{\mathrm{ji}}$ represents the variables likely to explain the technical inefficiency of the operators. Those used in this model are the age of the operator (Mabe et al., 2018); the operator's marital status; the size of the household, the level of education of the operator; the duration of the operator on the dams or his experience (Danso-Abbeam et al., 2015); social status (Messaoud et al., 2016); the place where the activity is practiced; the location of the activity around the dam or positioning of the plot in relation to the direction of water flow (Albouchi et al., 2007); membership in a dam maintenance group (Chebil et al., 2013); the distance from the operator's home to his place of business (Bhatt and Bhat, 2014); the type of water use; the existence of conflicts (Combelem, 2019) and the state of water and soil (Ouédraogo et al., 2018; Kouakou, 2017).

$\mathrm{V}_{\mathrm{i}}$ and $\varepsilon_{\mathrm{i}}$ are random variables representing the estimation errors and $\mathrm{U}_{\mathrm{i}}$ a random variable associated with the technical inefficiency of the operator. The random errors $V_{i}$ follow a normal distribution with mean 0 and variance $\sigma_{\mathrm{v}}^{2}$ and are independent of the technical inefficiencies $U_{\mathrm{i}}$. For the random errors associated with technical inefficiencies, they follow a normal distribution with mean $\mu$ and variance $\sigma_{u}^{2}$ and truncated to $0\left(U_{i} \geq 0\right)$. Finally, the random errors $\varepsilon_{\mathrm{i}}$ follow a truncated normal distribution with mean 0 and variance $\sigma_{\varepsilon}^{2}$ such that the truncation point is $\mu$.

Based on these assumptions, the parameters of the production frontier with technical inefficiency effects can be estimated simultaneously by the maximum likelihood method using the Frontier 4.1 program (Coelli, 1996). The results of these estimates provide the variances of the errors:

$$
\sigma^{2}=\sigma_{u}^{2}+\sigma_{v}^{2} ; \gamma=\frac{\sigma_{u}^{2}}{\sigma^{2}} \text { avec } 0 \leq \gamma \leq 1
$$

$\gamma$ measures the share of technical inefficiency in the total variation observed between the points on the production border and the data. $\sigma^{2}$ is the variance of the dependent variable and which is a function of the variation due to technical inefficiency $\sigma_{\mathrm{u}}^{2}$ and the variation due to the random error term $\sigma$. The application of this model required the mobilization of data on the production and characteristics of horticulturalists in the city of Ouagadougou.

\section{Data Sources and descriptives statistiques}

4.1. Data

This research uses primary data collected from 128 operators spread over the three dams: 42 operators from dam 1, 47 from dam 2 and 39 from dam 3 (see table 1). The sample elements were chosen according to the method of probability proportional to the size. It is a method that constructs the sample while respecting the distribution in the initial population according to the characteristics studied (Gadiaga, 1987). The latter were subjected to a questionnaire aimed to highlighting their level of production and the factors of production used.

The formula used is as follows:

$$
X_{i}=\frac{n \cdot n_{i}}{N}
$$

\footnotetext{
${ }^{1}$ CFA is the currency used in Burkina Faso and pegged to the Euro. One Euro equal to 655.957 CFA.
} 
$\mathrm{X}_{\mathrm{i}}$ represents the number of people to be investigated per dam; $n$ refers to the size of the sample considered in the study (128 horticulturalists); $\mathrm{n}_{\mathrm{i}}$ is the number of horticulturalists listed by dam; $N$ the total number of registered growers and $n_{i} / N$ is the relative frequency.

Table 1 : Distribution of respondents per dam

\begin{tabular}{ccccc}
\hline \hline Sites & $\mathbf{n}_{\mathbf{i}}$ & $\mathbf{n}_{\mathbf{i}} / \mathbf{N}$ & $\mathbf{n . n}_{\mathbf{i}} / \mathbf{N}$ & $\mathbf{X}_{\mathbf{i}}$ per site \\
\hline Dam 1 & 84 & 0.3281 & 41.99 & 42 \\
Dam 2 & 94 & 0.3671 & 46.98 & 47 \\
Dam 3 & 78 & 0.3046 & 38.98 & 39 \\
\hline Total (N) & 256 & 1 & 128 & 128 \\
\hline \hline
\end{tabular}

\subsection{Socio-demographic characteristics of operators}

The practice of horticulture in the city of Ouagadougou is carried out by men ( $94 \%$ of farmers). The low representation of women in horticulture activities could be largely linked to the arduousness of irrigation practices dominated by manual labor. More than $80 \%$ of those surveyed said they are married and less than $20 \%$ are single. The overall level of education is satisfactory. Only $39 \%$ of those surveyed are illiterate. The age of the operators varies between 21 and 58 years with an average of 36 years. Concerning the size of the households to which the horticulturalists come, it varies from 1 to 16 people or 6 people on average per household. The average area exploited is estimated at 0.0239 hectares. The daily amount of water withdrawn per operator varies from 40 to 1600 liters, or an average of 219 liters per day per operator.

Annual expenditure on inputs or fertilizers is about 46,200 FCFA per farmer on average. Average annual incomes of farmers vary from 100,000 to $4,700,000$ FCFA with an average of 894,000 FCFA. Among the operators, those with an annual income of 800,000 FCFA are the most numerous. For a country where a significant part of the population lives with less than one US dollar per day, such incomes are appreciable and remain largely above the poverty line at the national level estimated to 153,530 FCFA at current prices (INSD ${ }^{1}, 2014$ ).

\subsection{State of the water reservoirs}

Created since 1962, the water reservoirs of the city of Ouagadougou have experienced several types of pressure. These reservoirs are nowadays in poor condition according to the majority of operators (80\%) against only $20 \%$ who consider that they are in acceptable condition. Thus, $45.4 \%$ of the operators questioned maintain that dam number 1 is experiencing serious deterioration of its banks. For dam number 2, it is generally polluted (47.2\%). Finally, according to $27.5 \%$ of operators of dam number 3 , it suffers from lack of maintenance. Based on the perceptions of the operators themselves, the factors explaining the current state of the reservoirs are shown in Chart 1.

Chart 1: Perception of operators on the state of dams (in \%)

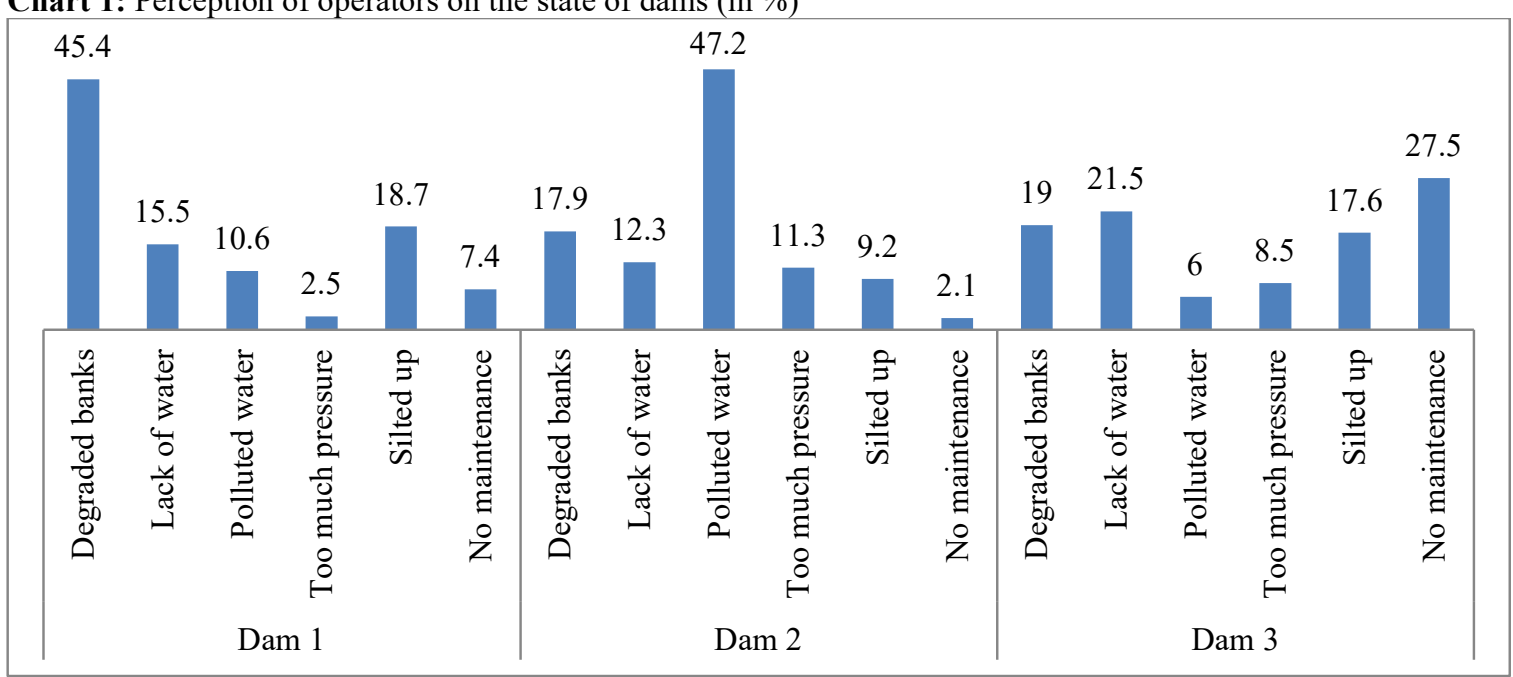

Faced with the degraded state of the dams, the identification of degradation factors is essential. According to the respondents, the deterioration factors come mainly from household waste $(69 \%)$. Indeed, the deterioration of the dykes favors a dumping of households' garbage in the dams. Graph 2 gives an overview of the different degradation factors of these dams.

\footnotetext{
${ }^{1}$ INSD is the National Institute for Statistics and Demography in Burkina Faso
} 
Chart 2 : Importance of degradation factors of dams (in \%)

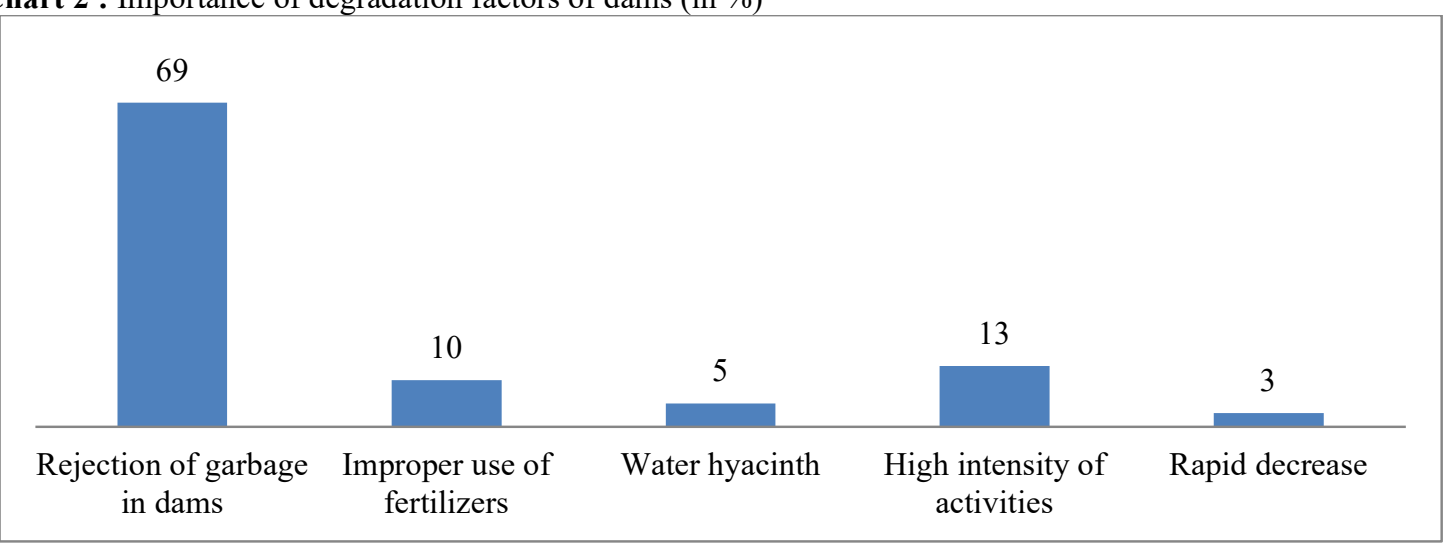

At the sanitary level, the various contacts with the water of dams generate water-borne diseases affecting the health of operators. The majority of those interviewed said they fell ill due to the condition of dams. Among these diseases, malaria is the most common $(83 \%)$.

\subsection{Distribution of operator efficiency's scores}

The estimation of the efficiency scores shows that horticulturalists have an average level of technical efficiency of 0.68 (Table 2). This level of efficiency shows that farmers still have opportunities to increase their production level without increasing the factors of production (Gniza, 2019). Indeed, an improvement in the state of the reservoirs could allow these operators to increase their production by $32 \%$ without having to increase their input volumes. Efficiency scores range from $49 \%$ to $78 \%$. These results show that horticulturalists are technically inefficient. The least efficient operator wastes a lot of resources. When an operator achieves the efficiency level of the most efficient operator in the sample studied, he could save up to $98 \%$ (1- (1/78)) of his production factors, and average operator could save $12 \%(1-(68 / 78))$ of his production capacity.

Table 2: Level of efficiency of horticulturists

\begin{tabular}{lcccc}
\hline \hline Statistics & Number & Average & Minimum & Maximum \\
\hline Horticulturists & 128 & 0.68 & 0.49 & 0.78 \\
\hline \hline
\end{tabular}

\section{Analysis of econometric results}

\subsection{Estimation of the stochastic production frontier}

Results of the production frontier estimation of translogarithmic type are summarized below:

Table 3: Results of the estimation of the production frontier function with effects of technical inefficiency

\begin{tabular}{lll}
\hline Variables & Coefficients & $\mathbf{P}>\mathbf{Z}$
\end{tabular}

\begin{tabular}{|c|c|c|}
\hline \multicolumn{3}{|c|}{ Production Function } \\
\hline Intercept & $38.21845^{*}$ & 0.083 \\
\hline L(amount of water withdrawn) & 3.135942 & 0.715 \\
\hline$L($ surface $)$ & -2.348639 & 0.730 \\
\hline L(input expenditure) & 7.625388 & 0.114 \\
\hline$L($ Quantity of workforce $)$ & $1.674036^{* * *}$ & 0.008 \\
\hline L(amount of water withdrawn $X$ amount of water withdrawn) $/ 2$ & 0.7885275 & 0.666 \\
\hline$L($ Surface $X$ surface $) / 2$ & -1.046564 & 0.413 \\
\hline$L($ input expenditure $X$ input expenditure $) / 2$ & -0.4026874 & 0.497 \\
\hline$L$ (quantity of workforce X quantity of workforce) $/ 2$ & 1.044282 & 0.110 \\
\hline$L$ (amount of water withdrawn) XL(surface) & 0.6077913 & 0.610 \\
\hline$L$ (amount of water withdrawn) XL(input expenditure) & -0.8979466 & 0.312 \\
\hline$L$ (Quantity of workforce) X L(amount of water withdrawn) & -0.0087054 & 0.991 \\
\hline$L($ surface $) X L($ input expenditure $)$ & 0.477598 & 0.473 \\
\hline$L($ Quantity of workforce $) X L($ surface $)$ & 0.0515176 & 0.944 \\
\hline$L$ (Quantity of workforce) X L(input expenditure) & -0.2803284 & 0.456 \\
\hline \multicolumn{3}{|c|}{ Variance Parameters } \\
\hline sigma $^{2}$ & $1.99 * * *$ & 0.000 \\
\hline Gamma & $0.26 * * *$ & 0.000 \\
\hline Log-Maximum Likelihood & -225.683 & \\
\hline
\end{tabular}




\begin{tabular}{|c|c|c|}
\hline Variables & Coefficients & $\mathbf{P}>\mathbf{Z}$ \\
\hline \multicolumn{3}{|c|}{ Determinants of inefficiency } \\
\hline Age of operator & $-0.0248757 * * *$ & 0.000 \\
\hline Quadratic effect of age & $0.0002564 * * *$ & 0.000 \\
\hline Marital Status & 0.0175832 & 0.465 \\
\hline Operator household size & $-0.0083828 *$ & 0.052 \\
\hline Educational level & $0.0361146^{* *}$ & 0.022 \\
\hline Time spend around the dams & -0.003591 & 0.177 \\
\hline Social Status & $0.0403459 * *$ & 0.018 \\
\hline Area of the activity & -0.0134631 & 0.480 \\
\hline Location of the activity & $0.038783 * * *$ & 0.008 \\
\hline Place of residence & $0.0058365^{*}$ & 0.081 \\
\hline Resort to other source of water & -0.0176565 & 0.487 \\
\hline Existence of conflicts & 0.01209 & 0.476 \\
\hline State of dams & $0.1046437 * * *$ & 0.003 \\
\hline
\end{tabular}

***: Significant at 1\%; **: Significant at 5\%; *: Significant at $10 \%$

The results from the estimation of the production function of trans logarithmic type show that the value of the gamma estimator $\gamma$ is equal to 0.26 and significant at $1 \%(\mathrm{P}<0.01)$. This result indicates the presence of stochastic technical inefficiency in horticulturalists. This gamma value illustrates that the variation in the units of production studied (difference between observed production and potential production compared to the border) is explained by the inefficiency of operators at only $26 \%$. Therefore, $74 \%$ of this variability is linked to random effects. In other words, this result indicates that the component attributable to operator inefficiency is lower than that associated with random factors. It is important to emphasize that the results presented in table 3 indicate that among the estimated coefficients of the production function, only that related to the quantity of workforce is significant at $1 \%$. Furthermore, we cannot directly interpret the $\beta$ coefficients resulting from the estimation of the translogarithmic functional form of production, given the existence of interaction effects. Therefore, it was necessary to calculate the partial elasticities with respect to the factors in order to see the influence of these variables. Table 4 presents the average elasticities of the production factors obtained from the estimation of the stochastic model.

Table 4: Elasticities of the production factors to the average of the sample

\begin{tabular}{ll}
\hline \hline Partial elasticity of production & \\
\hline Elasticity quantity of water & 3.135942 \\
Elasticity surface & -2.348639 \\
Elasticity expenditure & 7.625388 \\
Elasticity quantity of workforce & $1.674036^{* * *}$ \\
\hline \hline
\end{tabular}

From the results presented in Table 4 it turn out that the estimation of the average partial elasticities of the production factors, especially the quantity of water, the inputs expenditure and the quantity of workforce show a positive sign and reveal the importance of the impact of these factors on the production of horticulturalists with the exception of the surface used. This indicates that an increase in each of these factors leads to an increase in production.

However, out of the four (04) variables introduced into the model, only the variable quantity of work significantly influences the level of production obtained. Indeed, the partial elasticity of the input quantity of workforce was found to be significant at the threshold of $1 \%$, therefore an increase of $1 \%$ in the quantity of work used in production contributes to an increase of $1.67 \%$ in the production obtained. This result is consistent with that found by Nuama (2017), who showed that the use of workforce was a source of increased in food production in Ivory Coast.

About the variable "quantity of water", although its coefficient is positive, it does not seem to influence the production of horticulturalists. This result could be explained by the fact that in the agricultural field using a sprinkler system like horticulture; it is not the quantity of water withdrawn that is decisive in production but rather the efficiency of its use. This state of affairs had been highlighted by Mokrani (2009) who showed that 30 to $60 \%$ of irrigation water evaporates and does not benefit the crops. In other words, much of the water that evaporates is consumed unnecessarily and therefore will not have a significant effect on the quantity produced (Kang et al., 2017). Indeed, the remarkable increase in horticultural production levels necessarily involves more efficient use of water.

In addition, the cultivated area has no effect on the level of technical efficiency of operators in the city of Ouagadougou. This result is partially in line with that found by Kouakou (2017) stating that the cultivated area has a slightly significant and negative or even zero effect on the technical efficiency of urban farmers. Finally, 
expenditure on inputs has no significant effect on the technical efficiency of farmers.

\subsection{Determinants of the operators' technical inefficiency}

Analysis of the determinants of farmers' technical inefficiency shows that for flower production, the most significant variables are age, quadratic effect of age, size of the farmer's household, level of education, social status, location of the plot in relation to water flow, place of residence, and current condition of the dam.

Among these variables, those that reduce the technical inefficiency of operators are age, quadratic effect of age, size of the operator's household, level of education. Indeed, the results show that there is a negative and significant relationship at the $1 \%$ threshold between the age of the operator and the level of technical inefficiency. The older the farmers get, the more technically efficient they are in vegetable production. Otherwise, an increase in the operator's age by one year increases technical efficiency by 0.02487 . The most likely explanation for this result could be the experience gained in the farming of older farmers. Similar results have been reported by Chebil et al. (2013) who concluded that older operators are more experienced and efficient than younger operators. In addition, Kamiyama et al. (2016) and Selmi et al. (2015) reported that age has a positive effect on efficiency. For these authors, over time, the operator tends to develop a certain expertise and know-how concerning the best practices for using inputs, especially in the agricultural field. Ishiaku et al. (2017) found the same result with rice farms in Nigeria. On the other hand, the quadratic effect of age has a positive influence on the technical inefficiency of horticulturalists. This would mean that from a certain level, age acts negatively on the efficiency of operators, in the sense that the quadratic effect of age is positive on inefficiency at $5 \%$. This is explained by the fact that an operator who is too old will no longer have enough physical energy to irrigate his plot and control his production himself, and that would help to considerably reduce his productive efficiency. Similar conclusions have been reported by several authors (Ouédraogo et al., 2019; Ben Nasr et al., 2016; Konan, 2014; Sibiko et al., 2012; Coelli and Fleming, 2004). Indeed, the latter have shown in their studies that there is a negative effect of the aging of farmers on the efficiency of their farms.

The variable operator's household size has a negative impact on the technical inefficiency of operators at the $10 \%$ significance level. When the size of the operator's household increases by one person, the index of technical inefficiency decreases by 0.00838 units. This result confirms the fact that horticulture is an activity that uses a lot of workforce (Nuama, 2016). Authors such as Ouédraogo et al., (2019), Bhatt and Bhat (2014) and Kaboré (2007) have also shown that large households tend to be efficient in agricultural production because of the labor force that is generated.

The level of education of horticulturist is negatively correlated to the technical inefficiency of the operators at the $5 \%$. Indeed, the increase in the number of instructional years leads to a reduction in the technical inefficiency of operators by 0.03611 units. In other words, literate operators are technically more efficient than illiterates are. The positive effect of education has been revealed by several authors (Ogunmodede and Awotide, 2020, Kashiwagi, 2017; Messaoud et al., 2016; Ngom et al., 2016; Danso-Abbeam et al. 2015; Konan et al ., 2014; Lambaraa et al., 2007; Coelli and Fleming, 2004). In fact, for these authors, a literate farmer is very receptive to the accumulation of knowledge. In addition, the more literate the producers, the more easily they master modern production techniques and therefore they fully use their production capacity to optimize yields and increase their productive efficiency. Moreover, the more literate are farmers, the more is their opportunity to have the necessary information on supply, demand and market prices. Thus, they are part of a logic of profit maximization while seeking to minimize the risks linked to the uncertainty of future production.

On the other hand, the variables "social status of the operator, location of the plot in relation to the flow of water and poor condition of the water and soils" increase the technical inefficiency of operators in the framework of our research.

In addition, the coefficient of the variable "operator social status" is significant at the $5 \%$ level and positively correlated with the operator's technical inefficiency. Being indigenous and therefore a landowner increases the inefficiency by 0.04034 output units. As a result, natives who are both landowners are less effective than nonnatives are. These results are in contradiction with those of Messaoud et al. (2016) carried out in the irrigated perimeters of Sidi Thabet in Tunisia. In the context of our research, this result could be justified by the fact that most of the non-natives who have rented plots demonstrate a rational use of productive resources compared to native horticulturalists who are owners in order to be able to make their activity profitable.

The geographic position of the operation in relation to the flow of water also has a statistically significant effect at the $1 \%$ threshold on the level of technical inefficiency. The positive correlation between this variable and the level of technical inefficiency is distinguished. Thus, when one goes from an operator with his plot located downstream to an operator whose plot is located upstream from the dams, the level of technical inefficiency increases by 0.03878 units. In other words, the operators located downstream of the dams are more efficient. This result could be explained by the fact that operators located downstream of dams are better organized and access to water very easily, since the drying up of dams takes place quickly from upstream to downstream. Upstream operators lack water before downstream operators. This result is consistent with that found by Mokrani (2009) 
who showed that there is a close link between the amount of water available and the level of agricultural production. In addition, Dipama (2016) has shown that a low availability of water can result in a decrease in agricultural production with the consequence of reducing the efficiency of the production considered.

The state of dams also has a positive and significant impact on the technical inefficiency of production at the $1 \%$ threshold. The fact that the water in dams and the soils is in poor condition lead to a reduction in the technical efficiency of the operator by 0.02208 units. This result is in line with those found by Merhabi et al., (2019), Kouakou (2017) and Abraham (2010). Indeed, according to these authors, poor water quality increases the technical inefficiency of operators, in the sense that the use of poor quality or polluted water in horticulture characterized by the strong presence of heavy metals such as copper and zinc present health risks for horticulturalists (dermatoses, drying of the skin, and cracking of the feet). Likewise, the excessive increase in the phosphate and calcium contents of the soil following watering with wastewater can impede the normal growth of plants as noted by the horticulturalists but also cause diseases for plants (leaf spots, black spot, powdery mildew, etc.).

Finally, the poor quality of soil around the dams in the city of Ouagadougou, as shown by Ouédraogo et al., (2018), constitutes a real constraint limiting horticultural production. This poverty of soils, leads horticulturalists to carry out their cultures on soils enriched with in particular the compost of the gutters or various substrates (composts, droppings, etc.). Generally, horticulturalists use organic manure, chemical fertilizers, as well as various pesticides to improve production. Since they do not have the means to have a large quantity of these inputs, horticulturalists are therefore forced to produce small quantities. This is not without consequences for their productive efficiency.

\section{Conclusion and implications for economic policies}

The objective of this research was to estimate the level of technical efficiency of horticulturists around the dams in the city of Ouagadougou and to analyze the factors explaining the inefficiency of these operators. To reach this goal, we resort to the model of Coelli and Battesse (1995) by specifying a functional form of trans logarithmic type as well as the Tobit regression model to estimate the technical efficiency of the farmers.

Our findings indicates the presence of inefficiencies and random effects in the production of dam's operators. The average technical efficiency score for dam's operators was 0.68 . State otherwise, operators are technically inefficient. This inefficiency is largely due to random factors such as the poor condition of dams. Out of the variables introduced into the model, only the coefficient of the variable "quantity of workforce" significantly influences the level of output obtained. In fact, the partial elasticity of production in relation to the quantity of workforce used was significant at the $1 \%$ threshold, so a percentage increase in the quantity of workforce in production contributes to a $1.67 \%$ increase in the obtained output. With regard to the determinants, the Tobit regression model indicates that farmer age, household size and education level improve the technical efficiency of horticulturists. On the other hand, social status, the positioning of the plot in relation to the direction of water flow (upstream to downstream) and the poor state of water and soil increase the technical inefficiency of the same horticulturists.

From these findings, several implications for agricultural and dam protection policies are drawn. Concerning agricultural policies, the interventions of administrative and communal authorities should therefore focus on improving the technical efficiency of farmers through supervision and training and the adoption of good production techniques. About the protection of dams, actions to be carried out should focus on techniques for responsible water use and compliance with the rules established by the Nakambé Water Agency. All these measures will have to be subject to an institutional framework in order to make their implementation more effective. This research had the merit of measuring the technical efficiency level of urban horticulturists in a context characterized by the increasing scarcity of water resources. Moreover, it is in line with Goal 7 of Agenda 2063 for Africa, "Environmentally sustainable and climate resilient economies and communities", with the security of water supply as one of the priority areas. This goal is in line with Goal 6 of the MDGs "Ensure access to water and sanitation for all and sustainable management of water resources".

\section{References}

Abdulai S., Nkegbe P. K., Donkoh S. A. (2018), « Assessing the technical efficiency of maize production in northern Ghana: The data envelopment analysis approach ». Cogent Food and Agriculture, 4, p. 1-14.

Abraham O. (2010), «Agriculture urbaine et stratégies de survie des ménages pauvres dans le complexe spatial du district d'Abidjan. Revue électronique en sciences de l'environnement ». Vertigo, 10(2), 15p.

Agbodan M.M. et Amoussouga, G.F. (1995), Les facteurs de performance de l'entreprise. ed. AUPELF- UREF. John Libbey, Paris.

Aigner D.-J. \& Chu S.-F. (1968), « On estimating the industry production function ». American Economic Review, vol. 58, p. 826-839.

Aigner D, Lovell C. \& Schmidt P. (1977), « Formulation and estimation of stochastic frontier production models 
». J Econometrics vol. 6, p. 21-37.

Agence de l'eau du Nakambe (2015), Rapport général final : élaboration d'un manuel de surveillance et de d'entretien des barrages en terre au profit des usagers locaux, financement UE, IFEC, 48p.

Akerlof G. A. (1970), «The market for lemons: quality, uncertainly and the market mechanism ». Quarterly Journal of Economics Vol. 84, p. 488-500.

Albouchi L., Bachta M. S., \& Jacquet F. (2007), « Efficacités productives comparées des zones irriguées au sein d'un bassin versant. New Medit N. 3/2007, p. 4-13.

Amara N. \& Robert R. (2000), Mesure de l'efficacité technique : revue de la littérature, Centre de recherche en économie agro-alimentaire (CREA), $32 \mathrm{p}$.

Ambapour S. (2001), Estimation des frontières de production et mesures de l'efficacité technique, bureau d'application des méthodes statistiques et informatiques. BAMSI, Brazzaville, 26p.

Arrow K. J. (1974), The Limits of Organisations, New York, Norton, p86.

Atidegla S.C., Bonou W., Agbossou E.K. ( 2017), Relation entre perceptions des producteurs et surferlisation en maraîchage urbain et périurbain au Bénin.Int. J. Biol. Chem. Sci., 11(5): 2106-2118. DOI: http://dx.doi.org/10.4314/ijbcs.v11i5.14

Atinkpahoun C.N.H., Soclo H.M., Pons M-N., Leclerc J.P. (2018), Physico-chemicalcharacterization of domestic wastewaters in the "Nouvelle" agglomeration, Cotonou, Bénin. Int. J. Biol. Chem. Sci.,12(1): 542-557. DOI:http://dx.doi.org/10.4314/ijbcs.v12i1.42

Atkinson, S. E. \& Cornwell C., (1994), « Parametric measurement of technical and allocative inefficiency with panel data ». International Economic Review 35, p. 231- 244.

Bachewe F.N., Koru B., \& Taffesse A.S. (2015), Cereal productivity and its drivers: The case of Ethiopia. Strategy Support Program. Working Paper 75.

Battese G.-E., \& Coelli T. (1995), « A model of technical inefficiency effects in a stochastic frontier production function for panel data ». Empirical Economics, vol.20, p. 325-332.

Ben-Nasr J., Akkari T., Fouzai A., \& Bachta M.S. (2016), « Le mode d'accès à l'eau d'irrigation un déterminant de l'efficacité exploitations agricoles : Cas du périmètre irrigue de Sidi Ali Ben Salem, Kairouan-Tunisie ». Journal of New Sciences, Vol. 29,11p.

Bhatt M.S. \& Bhat S.A. (2014), « Technical efficiency and farm size productivity- micro level evidence from Jammu \& Kashmir ». International Journal of Food and Agricultural Economics, Vol. 2 No. 4, p. 27-49.

Boland J. (2005), Agriculture Urbaine : la Culture des Légumes en Ville. CTA, Série Agrodok (24) : 94.

Coulibaly A., Savadogo K., et Diakite L.(2017), Les Déterminants de l'efficience technique des riziculteurs de l'office du Niger au Mali. Journal of Agriculture and Environmental Sciences, Vol. 6, No. 2, pp. 88-97.

Bougaire D. (2008), Le secteur de l'eau au Burkina Faso : situation, défis, perspectives et rôle de la coopération, Projets GLOWA, Conférence internationale, Ouagadougou.

Charnes A., Cooper W., Rhodes E., (1978). Measuring the Efficiency of Decision Making Units ». European journal of operational research, p. 429-444.

Chebil A., Bahri W., \& Frija A. (2013), « Mesure et déterminants de l'efficacité d'usage de l'eau d'irrigation dans la production du blé dur : cas de Chabika (Tunisie) ». NEW MEDIT N, 1, p. 49-55.

Chogou S. K., Gandonou, E., \& FIOGBE, N. (2017), « Technical efficiency of small- scale pineapple production in Benin ». Cah. Agric, 26(2), 6p.

Christensen L.R., Jorgenson, D.W., \& Lau L.J. (1973), «Transcendantal Logarithmic Production Frontiers ». Review of Economics and Statistics, Vol 55, p. 28-45.

Coelli T., Rao P., \& Battese G. (1998), An introduction to efficiency and productivity analysis. Kluwer Academic Publishers, Massachusetts.

Coelli T. \& Fleming E. (2004), « Diversification economies and specialization efficiencies in a mixed food and coffee smallholder farming system in Papua New Guinea ». Agricultural Economics, Vol. 31, p. 229-239.

Combary S.O. \& Sawadogo K. (2014), « Les sources de la croissance de la productivité globale des facteurs dans les exploitations cotonnières du Burkina Faso ». Revue d'économie du développement, Vol 22, p. 61-82.

Combelem O., (2019), Contribution à la gestion durable des retenues d'eau dans les centres urbains au Burkina Faso : Cas des barrages de la ville de Ouagadougou. Thèse de Doctorat, Université Aube Nouvelle, Burkina Faso, 203p.

Conchita M.G., Sedego M.P. \& Cisse G. (2010), « Dynamique spatio temporelle de l'agriculture urbaine à Ouagadougou : Cas du Maraîchage comme une activité montante de stratégie de survie », VertigO - la revue électronique en sciences de l'environnement, Vol. 10, 20p.

Danso-Abbeam, G., Dahamani, A. M., \& Bawa, G. A.-S. (2015), « Resource-use- efficiency among smallholder groundnut farmers in Northern Region, Ghana ». American Journal of Experimental Agriculture, 6(5), 290304. Article no. AJEA.2015.087 ISSN: 2231-0606 SCIENCEDOMAIN international www.sciencedomain.org

Dieng F., Ngom D., Dia D., et Sy R. (2019), Efficience technique de la production d'anacarde (Anacardium 
occidentale L.) dans les grandes régions de production du Sénégal. Int. J. Biol. Chem. Sci. 13(6): 2627-2645.

Diop M., et Ka M.M.(2020), Assessment of the Allocative Efficiency of the WAEMU Banking Sector: An Application by the Method Stochastic Frontier Approach (SFA). IOSR Journal of Economics and Finance (IOSR-JEF). Vol. 11, p36-45

Djimasra N. (2009), Efficacité technique, productivité et compétitivité des principaux pays producteurs de coton. Economies et finances. Thèse de doctorat Université d'Orléans. p 408.

Douillet M., \& Girard P., (2013), Productivité agricole : des motifs d'inquiétude ? Notes 7, FARM, 12p.

Farrell M. J. (1957), « The measurement of productive efficiency. Journal of the Royal Statistical Society, series A, general 120 , p. 253-282.

Fuglie K. \& Rada N. (2013), « Resources, policies, and agricultural productivity in Sub- Saharan Africa». ERR145, Economic Research Service/USDA.

Gniza I.D. (2019), Analyse des différences d'efficacité entre les sexes des exploitations de riz dans le département de Divo, en Côte d'Ivoire. Journal of Economics and Finance.Vol. 10, pp63-69.

Gunter C-B \& Chauveau T. (2002), The pricing of options and corporate liabilities, Dictionnaire des grandes œuvres économiques, Paris, Dalloz.

Huang C.J. \& Liu J.T. (1994), « Estimation of a non-neutral stochastic frontier production function. Journal of Productivity Analysis, vol. 5, p. 171-180.

Kabore D.P. (2007), Efficience technique de la production rizicole sur les périmètres aménagés du Burkina Faso. Série document de travail dt-CAPES n²007, 35p.

Kambou D. (2019), Évaluation des performances techniques de l'irrigation au Burkina Faso. Thèse de Doctorat, UNIVERSITÉ DE LIÈGE - GEMBLOUX AGRO - BIO TECH, 190p.

Kamiyama H., Kashiwagi K., \& Kefi M. (2016), « Technical efficiency among irrigated and non-irrigated olive orchards in Tunisia ». African Journal of Agricultural Research. Vol. 11(45), p. 4627-4638.

Kang S., Hao X., Du T., Tong L., Su X., Lu H., Li X., Huo Z., Li S. \& Ding R., (2017), « Improving agricultural water productivity to ensure food security in China under changing environment: From research to practice ». Agricultural Water Management, Vol. 179, p. 5-17.

Kashiwagi K. (2017), « Technical Efficiency of Olive-growing Farms in the Northern West Bank of Palestine. Faculty of Humanities and Social Sciences, Alliance for Research on North Africa, University of Tsukuba, Tsukuba, Japan ». Published by Canadian Center of Science and Education. Sustainable Agriculture Research; Vol. 6, No. 2.

Konan Y.R., Akanvou L., N'cho S., Arouna A., Eddy B., \& Kouakou C.K. (2014), « Analyse de l'efficacité technique des riziculteurs face à l'infestation des cultures par les espèces parasites striga en Côte d'Ivoire ». Rev. Ivoir. Sci. Technol., 23 (2014), p. 212-223.

Kouakou K.P. (2017), « Analyse de la performance productive de l'agriculture urbaine dans le District d'Abidjan ». European Scientific Journal, Vol.13, p. 288-301.

Leibenstein (1966), « Allocative Efficiency versus X-Efficiency ». American Economic Review, June p.392-415.

Liu J., Zhang C., Hu R., Zhu X., and Cai J. (2019), Aging of Agricultural Labor Force and Technical Efficiency in Tea Production: Evidence from Meitan County. Sustainability, Vol.11, 16p.

Mabe F. N., Donkoh S. A., \& Al-Hassan S. (2018), « Accounting for rice productivity heterogeneity in Ghana: The two-step stochastic metafrontier approach ». International Journal of Agricultural and Biosystems Engineering, 12(8), p. 223-232.

Messaoud E., Ghaier M.T.S, Aichi H., Beji M.F., \& Zaibet L. (2016), « Analyse de l'efficacité technique des exploitations agricoles: Cas du périmètre irrigué de la région de Sidi Thabet ». Journal of new sciences Agriculture and Biotechnology, Vol. 5, p. 1228-1232.

Merhabi F., Amine H. \& Halwani J., (2019), « Evaluation de la qualité des eaux de surface de la rivière Kadicha ». Journal Scientifique Libanais. 20(1), p. 10-34.

Ministère de l'Economie des Finances et du Développement (2016), Schéma Nationale d'Aménagement et de Développement Durable du Territoire (SNADDT).DGDT, MINEFID, Burkina Faso, 172p.

Mokrani A., (2009), « L'eau et les activités agricoles ». Planet-Vie, 10p.

Ndiaye M. (2018), « Analyse de l'efficacité technique des exploitations agricoles familiales à Maurice ». European Scientific Journal, Vol.14, p. 143-160.

Ngom C.A.B., Sarr F., \& Fall A. A., (2016), « Mesure de l'efficacité technique des riziculteurs bassin du fleuve Sénégal ». Économie rurale, 355 | 2016, p. 91-105.

Nuama E., (2017), « Mesure de l'efficacité technique des agricultrices de cultures vivrières en Côte d'Ivoire ». Économie rurale (En ligne), 296 | Novembre-décembre 2006, mis en ligne le 28 octobre 2009, consulté le 30 septembre 2016. URL: http://economierurale.revues.org/1892 ; DOI : 10.4000/ economierurale.1892.

Ogunmodede A.M. \& Awotide O.D., (2020), « Profitability and technical efficiency of leafy vegetable production: a stochastic frontier production function analysis ». International Journal of Vegetable Science, DOI: 10.1080/19315260.2019.1711283. 
Ouédraogo J-B. (2010), Vulnérabilités sociales de Ouagadougou. CLUVA, 35p.

Ouédraogo B.I., Zahonogo P., \& Ouédraogo S., (2019), « Determinants of the Technical Efficiency of Maize Farmers in Burkina Faso ». Journal of Economics and Sustainable Development, Vol.10, No.14, p. 55-67.

Ouedraogo D.B., Gnankambary Z., Nacro H.B., \& Sedogo P., (2018), « Caractérisation et utilisation des eaux usées en horticulture dans la ville de Ouagadougou au Burkina Faso ». Int. J. Biol. Chem. Sci. 12(6): $2564-$ 2577.

Selmi S., Ben A. S., \& Hadded S. (2015), « Accès aux crédits bancaires et efficience technique des exploitations agricoles dans les périmètres irrigués du gouvernorat de Tataouine dans le Sud-Est tunisien ». New Medit N. 1, p. $75-80$.

Sibiko K. W. \& al., (2012), « Analysis of determinants of productivity and technical efficiency among smallholder common bean farmers in eastern Uganda ». Current Research Journal of Economic Theory, Vol 53, p. 4455.

Stiglitz J. E. (1977), «Monopoly nonlinear pricing and imperfect information: the insaurance market». Review of Economics Studies, Vol 44, p. 407-430.

Tidjani O.M.M., Issoufou A., Rabani A. et Zeinab S. (2018), Contamination potentielle des aliments par des polychlorobiphényles (PCBs): connaissance du polluant et évaluation de la perception du risque.Int. J. Biol. Chem. Sci., 12(1): 168-179. DOI: https://dx.doi.org/10.4314/ijbcs.v12i1.13

Williamson O.E. (1985), The economic institutions of capitalism: firms, markets, relational contracting. Free Press, New York, 450p.

Yameogo S. (2008), Ressources en eau souterraine du centre urbain de Ouagadougou au Burkina Faso : qualité et vulnérabilité. Thèse de doctorat, Université d'Avignon et des Pays de Vaucluse, 254p.

Yonkeu S. \& Mamane C. (2007), Développement d'un modèle écosytémique de petites retenues d'eau au sahel : Application au barrage de Yitenga au Burkina Faso ». 2IE, 8p.

Zongo B., Diarra A., Barbier B., Karambiri M.Z.H., Ouedraogo S., Toe P., Hamma Y., Dogot T. (2019), Évaluation ex ante de l'irrigation de complément dans un contexte sahélien : couplage d'un modèle biophysique à un modèle économique d'exploitation agricole. Biotechnol. Agron. Soc. Environ, vol.23, 14p.

Zoungrana T. D. \& Combelem O. (2016), « Déterminants de la participation des populations riveraines à la protection des retenues d'eau en milieu urbain : Cas des barrages $n^{\circ} 1,2$ et 3 de la ville de Ouagadougou au Burkina Faso ». Revue Internationale de Gestion et d'Economie, vol 2, p. 215-240.

Zoungrana T. D. (2017), Valeur économique de la protection des petites retenues au: cas du barrage de Yitenga dans la province du Kourritenga au Burkina Faso; Editions Universitaires Européennes, 201p. 